\title{
DETECTION OF ENTEROTOXIGENIC STAPHYLOCOCCUS AUREUS IN SOME MEAT PRODUCTS
}

\author{
ALAA EL-DEEIN M. MORSHDY; ADEL I. EL-ATABANY; MOHAMED A. HUSSEIN and \\ MOHAMMAD AL-AMEN SH. NASR
}

Faculty of Vet. Med. - Food Hygiene Department (Meat Hygiene) Zagazig University.

\begin{tabular}{ll}
\hline & ABSTRACT \\
\hline Received at: 18/3/2013 & $\begin{array}{l}\text { Eighty four meat product samples (minced meat, sausage and beef burger 28 of } \\
\text { each) were collected and examined for detection of Staphylococcus aureus. The } \\
\text { mean count was } 4.3 \times 10^{2}, 5.1 \times 10^{3} \text { and } 8.7 \times 10^{3} \mathrm{cfu} / \text { gm, respectively. Multiplex }\end{array}$ \\
$\begin{array}{l}\text { Accepted: 14/4/2013 } \\
\text { Polymerase Chain Reaction (PCR) was applied for detection of genes responsible } \\
\text { for enterotoxins production from identified coagulase positive Staphylococcus } \\
\text { aureus. The predominant genes were A and B. They were detected in examined } \\
\text { sausage and beef burger samples with different percentages. }\end{array}$
\end{tabular}

Key words: Detection, Meat products, Staphylococcus aureus, Staphylococcal enterotoxins, Multiplex PCR.

\section{INTRODUCTION}

Meat and meat products are considered the most important sources of food for people in every where as they supply the consumers with the required nutritive elements such as high quality proteins, essential amino acids, B-complex vitamins and certain minerals especially iron and phosphorous and beside that the meat has high calories value.

In comparison to fresh meat, meat products retain more consumers' palatability and easily preparation characteristics. Food safety is a global health goal and the food borne diseases take a major crisis on health. Therefore, detection of microbial pathogens in food is the solution to the prevention and recognition of problems related to health and safety (Velusamy et al., 2010). Staphylococcus aureus (S. aureus) is a major cause of food borne intoxication and its presence in food constitutes an important problem for food processors, food service workers and consumers. The main reservoirs of $S$. aureus are humans and animals. Healthy people carry the organism in their nose and throat (50\%), on their hands (5-30\%), and in wounds. S. aureus can also colonize food contact surfaces, and it can become a persistent organism in slaughter houses. S. aureus can contaminate foods through contact with contaminated hands, materials and surfaces, but also via the air coughing (Rao et al., 1980). Considering this hazard, meat and meat products should not be subjected to unnecessary contamination and they should be free from such serious pathogen to ensure a maximum margin of consumer safety.

S. aureus, if posses Staphylococcal enterotoxins genes may produce several enterotoxins (SEA to SEJ) (Monday and Bohach, 1999). Staphylococcal food poisoning (SFP) is one of the most prevalent causes of gastroenteritis worldwide. Symptoms of SFP have a rapid onset characterized by abdominal cramps, nausea, and vomiting, sometimes followed by diarrhea. Patients usually suffer from symptoms within 2-4 hours after ingestion of thermostable Staphylococcal enterotoxins (SEs). The approximate dose of SEs ranged from 0.1 to $1.0 \mathrm{mg} / \mathrm{kg}$ of body weight (Jorgensen et al., 2003 and Stewart et al., 2005). Since SEs are more stable than S. aureus bacteria, it is possible to test food product and obtain negative $S$. aureus culture results and positive SE tests. Today, up to 15 SEs are known; the last one discovered was the recently identified SEU (Letertre et al., 2003a). Multiplex PCR assay for detection of Staphylococcal enterotoxins genes (SEA, SEB, SEC, SED and SEE) was developed and proved to be specific, sensitive, and rapid method. (Omoe et al., 2002 and Zschock et al., 2005). There fore the current study was planed to through light on the incidence and count of $S$. aureus followed by PCR identification of enterotoxigenic strains.

\section{MATERIALS and METHODS}

\section{Sampling:}

Eighty four meat product samples (minced meats, sausages and burgers) 28 of each were collected randomly from supermarkets and butchery shops at Sharkia province, Egypt, at different levels of sanitations. The collected samples were identified, packed in sterile polyethylene bags and transferred to the laboratory as soon as possible.

\section{Methodology:}

The collected samples were examined for detection of $S$. aureus by ordinary culture method followed by biochemical identification and examined for coagulase enzyme production and then the detected strains were subjected to DNA extraction which was 
used as template of PCR amplification for detection of $S$. aureus enterotoxins genes.

Preparation of samples, (ICMSF, 1978):

Twenty five grams of each examined samples were transferred to a sterile polyethylene bags, and $225 \mathrm{ml}$ of $0.1 \%$ of sterile buffered peptone water was aseptically added to the content of the bag. Each sample was homogenized in a blender at $2500 \mathrm{rpm}$ for 1-2 minute to provide homogenate of $1 / 10$ dilution. One $\mathrm{ml}$ from the original dilution was transferred to another sterile tube containing $9 \mathrm{ml}$ sterile buffered peptone water and mixed well to make next dilution, from which further decimal serial dilutions were prepared. Then, dilutions were subjected to the following examinations.

Count and isolation of Staphylococcus aureus, (APHA, 1992):

From the previously prepared decimal dilutions of the examined samples $0.1 \mathrm{ml}$ was transferred and evenly spread on dry surface of Baired-Parker agar medium plates (Oxoid, 1998). Inoculated and control plates were incubated at $37^{\circ} \mathrm{C}$ for 48 hours and Staphylococci count was calculated and recorded. Each suspected colony (black shiny with narrow white margin and surrounded by clear hallow-zone extended into the opaque medium) was picked up and cultured on slope agar for further biochemical identification according to (APHA, 1992).

\section{Identification of isolated Staphylococci organisms:}

\section{- Morphological characters:}

Staining (microscopical examination):

Films were made from the pure culture of isolated organisms stained by Gram's stain and examined microscopically. Gram +ve, grapes shape, cocci were considered as positive Staphylococci.

\author{
- Biochemical reactions: \\ 1- Catalase test. \\ 2- Oxidation-fermentation test. \\ 3- Coagulase test. \\ 4- Mannitol test.
}

\section{PCR detection of Staphylococcal enterotoxins genes:}

Extraction of the DNA from Bacterial culture:

Bacterial DNA was extracted using GeneJET Genomic DNA Purification kit (Fermentase, USA \# $\mathrm{k} 0722$ ) following the manufacture's protocols.

\section{PCR assays:}

Oligonucleotide sequences of SE genes' were listed in table (1). PCR amplification was performed in a thermal cycler (Thermal cycler: PTC-100 TM programmable thermal controller, Peltier-Effect cycling, MJ, RESEARCH, INC.) with an initial denaturation of $94^{\circ} \mathrm{C}$ for 5 minutes; 35 cycles of amplification (denaturation at $94^{\circ} \mathrm{C}$ for 2 minutes, annealing at $57^{\circ} \mathrm{C}$ for 2 minutes, and extension at $72^{\circ} \mathrm{C}$ for 1 minute), with a final extension at $72^{\circ}$ $\mathrm{C}$ for 7 minutes. Electrophoration was done using $1.5 \%$ agarose gel in $0.5 \%$ Trisacetate- EDTA (TEA) buffer, stained with ethidium bromide. The amplified products then were visualized using ultra violet lamp wherein, the images were taken.

Multiplex PCR for detection of selected Staphylococcal genes:

The reaction conditions for the multiplex PCR assay were optimized to ensure that all of the target gene sequences were satisfactorily amplified. The primers were designed to target the coding regions of the genes; care was taken to avoid areas of homology within the structural genes for the enterotoxins. The primers used in each set had almost equal annealing temperatures, which reduced the possibility of occurrence of unwanted bands originating from nonspecific amplification.

Table 1: Nucleotide sequences, gene locations, and anticipated sizes of PCR products for the S. aureus genespecific oligonucleotide primers used in this study (Mehrotra et al., 2000).

\begin{tabular}{|c|c|c|c|c|}
\hline Gene & primer & $\begin{array}{c}\text { Location } \\
\text { within } \\
\text { gene } \\
\end{array}$ & Sequence $\left(5^{`}-3\right)$ & $\begin{array}{c}\text { Size of amplified } \\
\text { product }\end{array}$ \\
\hline \multirow{2}{*}{ sea } & GSEAR-1 & $349-368$ & GGTTATCAATGTGCGGGTGG & \multirow{2}{*}{102 bp } \\
\hline & GSEAR-2 & $431-450$ & CGGCACTTTTTTCTCTTCGG & \\
\hline \multirow{2}{*}{ seb } & GSEBR-1 & $666-685$ & GTATGGTGGTGTAACTGAGC & \multirow[t]{2}{*}{164 bp } \\
\hline & GSEBR-2 & $810-829$ & CCAAATAGTGACGAGTTAGG & \\
\hline \multirow{2}{*}{$\sec$} & GSECR-1 & $432-455$ & AGATGAAGTAGTTGATGTGTATGG & \multirow{2}{*}{$451 \mathrm{bp}$} \\
\hline & GSECR-2 & $863-882$ & CACACTTTTAGAATCAACCG & \\
\hline \multirow{2}{*}{ sed } & GSEDR-1 & $492-514$ & CCAATAATAGGAGAAAATAAAAG & \multirow{2}{*}{$278 \mathrm{bp}$} \\
\hline & GSEDR-2 & $750-769$ & ATTGGTATTTTTTTTCGTTC & \\
\hline \multirow{2}{*}{ see } & GSEER-1 & $237-257$ & AGGTTTTTTCACAGGTCATCC & \multirow{2}{*}{209 bp } \\
\hline & GSEER-2 & $425-445$ & CTTTTTTTTCTTCGGTCAATC & \\
\hline
\end{tabular}




\section{RESULTS}

Table 2: Incidence and count of S. aureus in examined meat product samples and its percentage $(\mathrm{n}=28)$.

\begin{tabular}{lcccccc}
\hline Product & No of +ve samples & percentage & Min & Max & Mean** & \pm S.E* \\
\hline Mince meat & 6 & $21.4 \%$ & $<100$ & $10 \times 10^{3}$ & $4.3 \times 10^{2 \mathrm{~b}}$ & $3.6 \times 10^{2}$ \\
\hline Sausage & 11 & $39.3 \%$ & $<100$ & $40 \times 10^{3}$ & $5.1 \times 10^{3 \mathrm{a}}$ & $2.1 \times 10^{3}$ \\
\hline Burger & 17 & $60.7 \%$ & $<100$ & $30 \times 10^{3}$ & $8.7 \times 10^{3 \mathrm{a}}$ & $1.8 \times 10^{3}$ \\
\hline ' Min: minimum. & & & & & \\
" Max: maximum. \\
** Means carrying the different letter were significant; $(\mathrm{P}<0.05)$. \\
* S.E: Standard error of mean.
\end{tabular}

Table 3: Incidence of enterotoxins of coagulase positive $S$. aureus detected in examined meat product samples and its percentage.

\begin{tabular}{ccccccccc}
\hline \multirow{2}{*}{ Product } & \multirow{2}{*}{$\begin{array}{c}\text { No of +ve } \\
\text { samples }\end{array}$} & $\begin{array}{c}\text { \% of +ve } \\
\text { samples }\end{array}$ & \multicolumn{2}{c}{ Enterotoxin A } & \multicolumn{2}{c}{ Enterotoxin B } & \multicolumn{2}{c}{$\begin{array}{c}\text { Enterotoxins } \\
\text { A\&B }\end{array}$} \\
\cline { 5 - 9 } Minced meat & 0 & $0 \%$ & 0 & $0 \%$ & 0 & $0 \%$ & No & $\%$ \\
\hline Sausage & 9 & $32.1 \%$ & 8 & $88.9 \%$ & 1 & $11.1 \%$ & 0 & $0 \%$ \\
\hline Burger & 8 & $28.6 \%$ & 6 & $75 \%$ & 1 & $12.5 \%$ & 1 & $12.5 \%$ \\
\hline
\end{tabular}

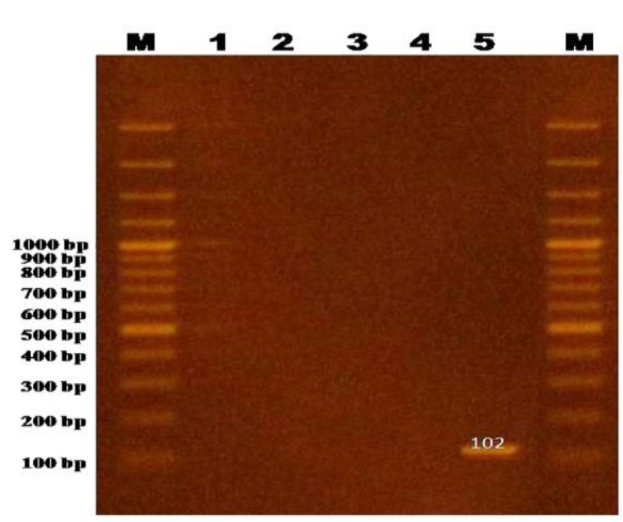

(1)

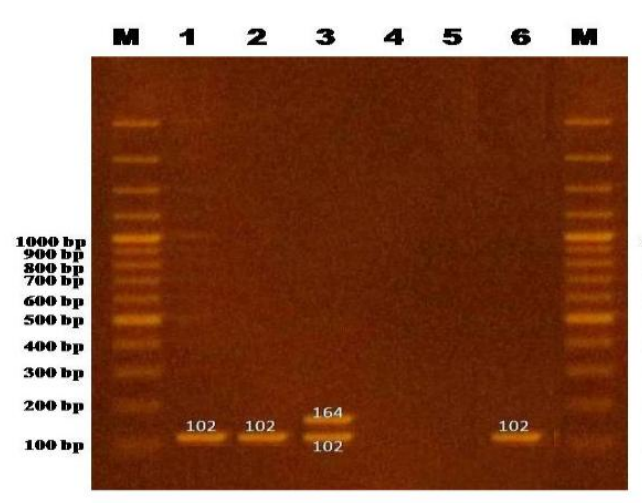

(3)

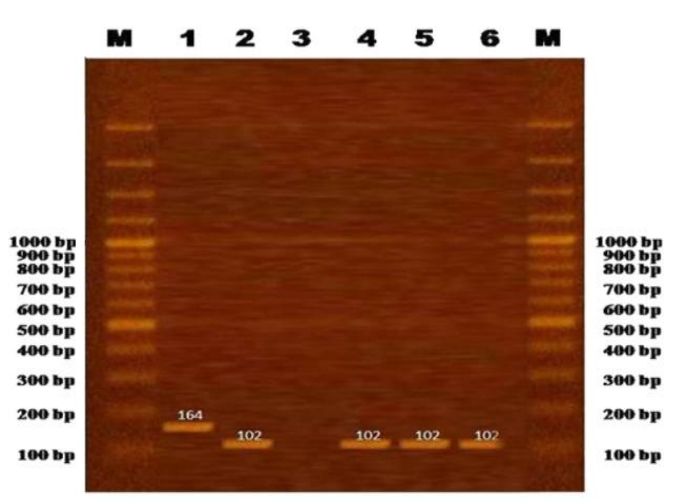

(2)

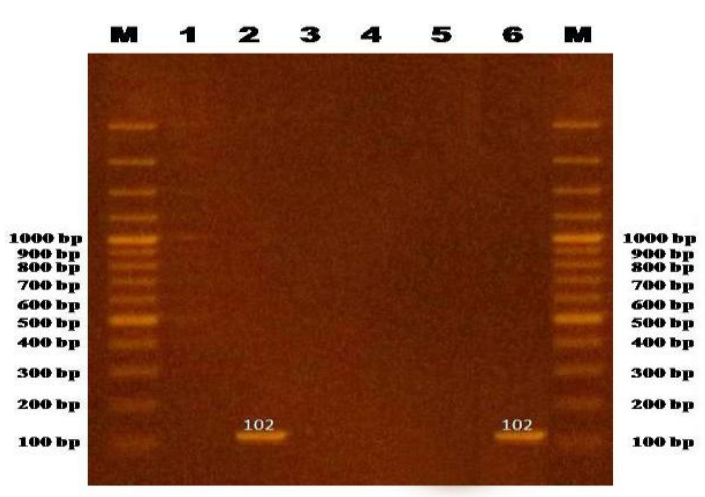

(4) 


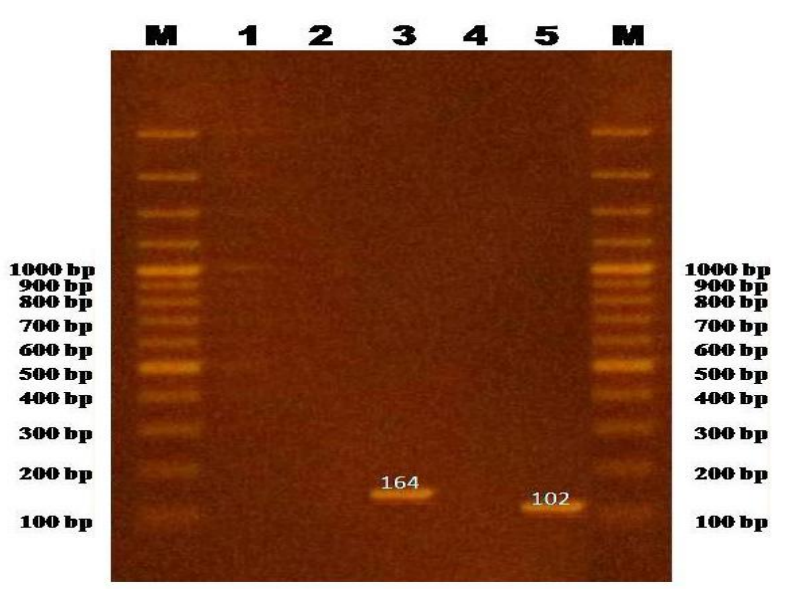

(5)

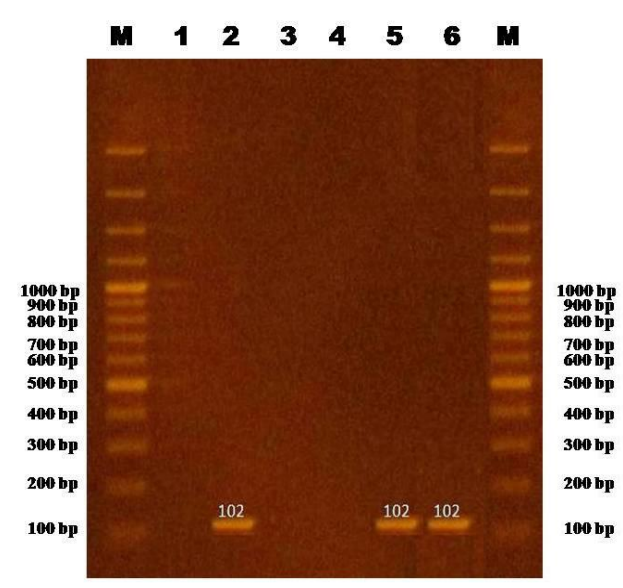

(6)

Figureure: Agarose gel electrophoretic pattern of: - 1,2 minced meat samples; 3, 4, 5 sausage samples. - 3 minced meat samples; 1, 2,4,5,6 sausage samples. - 1, 2 sausage samples; $3,4,5,6$ beef burger samples. - 6 sausage samples; 1, 2,3,4,5 beef burger samples. - 1,2, 4 minced meat samples; 3,5 beef burger samples. $-1,2,3,4,5,6$ beef burger samples.

\section{DISCUSSION}

\section{Staphylococcus aureus count:}

Staphylococcal food-poisoning (SFP) is caused by Staphylococcal enterotoxins (SEs) produced during massive growth of $S$. aureus in food. SFP is a prevalent cause of food-borne disease worldwide, (Jablonski and Bohach, 2001).

The results showed in table (2) revealed that, the incidence of S. aureus in minced meat was 6 (21.4\%) similar result was recorded by Vorster et al. (1994) while lower incidence was detected by El-Said (2005). Higher incidences were recorded by Depourcq and Poucke, (1991); El-Gohary (1993); Ramasastry (1999); Salek (2000); Huffman (2002) and Tavakoli and Riazipour (2008). The mean count was $4.3 \times 10^{2} \pm 3.6 \times 10^{2} \mathrm{cfu} / \mathrm{gm}$ and the count ranged from $<10^{2}$ to $10 \times 10^{3} \mathrm{cfu} / \mathrm{gm}$. Such results were lower than that recorded by Tharwat (2008) and Nossier (2010).

In sausage samples, the incidence was 11 (39.3\%). This incidence was similar to that obtained by ELSherbeeny et al. (1990) who detect $S$. aureus in $43.1 \%$ of examined sausage samples. On contrary lower incidences were reported by Abd El-Aziz et al. (1996); Soultos et al. (2003); El-Said (2005) and Gehad et al. (2006). Higher incidences were recorded by Rashad (1990), El-Gohary (1993) in the examined sausage samples.

The mean value was $5.1 \times 10^{3} \pm 2.1 \times 10^{3} \mathrm{cfu} / \mathrm{gm}$ with a minimum of $<10^{2}$ and a maximum of $40 \times 10^{3} \mathrm{cfu} /$ gm. Lower results were obtained by El-Mossalami,

(2002) who found that $S$. aureus count was $<50$ cfu/gm and Gehad et al. (2006) whom failed to detect $S$. aureus in the examined sausage samples.

Burger samples showed a high incidence of 17 (60.7 $\%$ ), while lower incidences were reported by Ranucci et al. (2004) they isolated S. aureus from $21.1 \%$ of the examined hamburgers also El-Said (2005) recorded that $S$. aureus was isolated from frozen beef burger with an incidence of $2(4 \%)$ and Shahraz et al. (2012) isolated 64 (24\%) S. aureus strains from 256 samples of packaged hamburger. The mean value was $8.7 \times 10^{3} \pm 1.8 \times 10^{3}$ organisms/gm with a minimum of $<10^{2}$ and a maximum of $30 \times 10^{3}$ organisms/ gm. Lower count was recorded by Essa and Makar, (2003).

Comparatively, the obtained results declared that burger samples gave a higher incidence of $S$. aureus followed by sausage then minced meat. This indicates that the unsanitary handling of the prepared meat products during processing, transportation and marketing. Also, was due to using a low quality meat and meat additives. The shape of burger may explain the higher incidence than that of sausage. Statistical analysis revealed that both sausage and burger were significantly higher than minced meat at $\mathrm{p}$ value < 0.05 .

The United Kingdom Public Health Laboratory Service in 2000 classified meat products to four categories satisfactory, acceptable, unsatisfactory and unacceptable according to number of $S$. aureus as < 20,20 to $<100,100$ to $<10^{4}$ and $\geq 10{ }^{4} \mathrm{CFU} / \mathrm{g}$, respectively. We found that, all examined minced 
meat samples were within the permissible limit and considered acceptable except only one sample that show unsatisfactory level of contamination $\left(10 \times 10^{3}\right.$ organisms/ gm).The examined samples of sausage and burger showed unsatisfactory level of contamination and were $11(39.3 \%)$ and $17(60.7 \%)$ for sausage and burger.

PCR assays used to identify the pathogen and its enterotoxin genes in food samples. The PCR assays could be made in hours rather than days, with a high sensitivity and method accuracy, allowing for the detection of very low concentrations of microorganisms (Najera-Sanchez et al., 2003).

Data in table (3) revealed that the incidence of identified enterotoxigenic $S$. aureus isolated from meat product samples by PCR technique was 9 (32.1 $\%)$ from sausage and $8(28.6 \%)$ from burger, while it couldn't be detected from minced meat. Nearly similar result was detected by Pinto et al. (2005). They found that forty out of 131 isolates $(31 \%)$ tested were positive for enterotoxins production. Lower incidence of enterotoxins was detected by Kevin et al. (2009). They examined 155 samples of fermented pork product, and found that $39.35 \%$ of the samples were positive for $S$.aureus, but none were positive for the Staphylococcal enterotoxins. Higher incidence of enterotoxigenic $S$. aureus was detected by $\mathrm{Oh}$ et al. (2007) they found that $47 \%$ of the isolated $S$. aureus strains from the contaminated meat product were enterotoxigenic $S$. aureus. Also, El-Shater (2010) detect enterotoxigenic S. aureus with an incidence of $(55.6 \%)$ in sausage samples and Aydin et al. (2011) found that out of $147 \mathrm{~S}$. aureus isolated from different foods including sausage, 92(62.6\%) were enterotoxigenic S. aureus.

Enterotoxins are a group of serologically distinct proteins (A, B, C1-3, D, E and F) that are the causative agents of Staphylococcal food poisoning. Although their exact mode of action has yet to be fully elucidated, they are believed to stimulate an enteric-vagus nerve reflex triggering the vomiting centers of the brain (Sears and Kaper, 1996; Arbuthnott et al., 1990). The enterotoxins can also act as super antigens, stimulating $\mathrm{T}$ lymphocytes to release cytokines and $\mathrm{T}$-cell proliferation (Balaban and Rasooly, 2000; Krakauer, 1999).

The predominant enterotoxins isolated from examined sausage samples were enterotoxin A 8 $(88.9 \%)$ figures $(1,2,3$ and 4) detected at $102 \mathrm{bp}$ then enterotoxins B 1 (11.1\%) figure (2) detected at $164 \mathrm{bp}$. Application of PCR assays for detection of enterotoxin production from coagulase positive $S$. aureus isolated from beef burger samples revealed that $6(75 \%)$ enterotoxin A detected at $102 \mathrm{bp}$ figures (3, 4,5 and 6), followed by enterotoxin B figure (5) detected at $164 \mathrm{bp}$. With a percentage of 1 (12.5\%) and enterotoxins A and B figure (3) detected in one sample at 102 and $164 \mathrm{bp}$. With a percentage of
$(12.5 \%)$. Such results substantiate what have been reported by Hwang et al. (2007); Ruzickova et al. (2008); El-Shater (2010) and Aydin et al. (2011).

\section{Finally we conclude that:}

Not all coagulase positive $S$. aureus are enterotoxigenic, since minced meat samples were negative, only nine sausage samples from eleven coagulase positive were enterotoxigenic $(82 \%)$ and only eight burger samples from seventeen coagulase positive were enterotoxigenic $(47 \%)$.

\section{REFERENCES}

Abd El-Aziz, A.S.; El-Neklawy, E.; Hussien-Azza and Niazi- Zeineb (1996): Food poisoning Microorganisms in Some Local Meat Products. Vet. Med. J., Giza. 44 (4), 691-698.

APHA (1992): Compendium of methods for the microbiological examination of food. 3rd Ed., Washington, D. C., USA.

Arbuthnott, J.P.; Coleman, D.C. and De Azavedo, J.S. (1990): Staphylococcal toxin in human disease. Soc Appl. Bacteriol. Symp Ser69, 101S-107S.

Aydin, A.; Sudagidan, M. and Muratoglu, K. (2011): Prevalence of Staphylococcal enterotoxins, toxin genes and genetic-relatedness of foodborne Staphylococcus aureus strains isolated in the Marmara Region of Turkey. Int.J. Food Microbiol., 148 :99-106.

Balaban, N. and Rasooly, A. (2000): Staphylococcal enterotoxins. Int J Food Microbiol., 61: 1-10.

Beuchat, T.J. (2001): Montville, Editors, Food Microbiology Fundamentals and Frontiers (2nd ed.), ASM Press, Washington, D.C., USA, pp. 411-434.

Depourcq, G. and Poucke, L.V. (1991): Evaluation of the microbiological quality of minced meat. Lab. For pharmaceutical microbial. Hygiene Univ. of Gent. Harelbekes traat 72, B. 9000 Ghent, Belgium.

Doyle, L.R. Letertre, C.; Perelle, S.; Dilasser, F. and Fach, P. (2003b): Identification of a new putative enterotoxin SEU encoded by the egc cluster of Staphylococcus aureus. J. Appl. Microbiol., 95, 38-43.

El-Gohary, A.H. (1993): Sausage and minced meat as a source of food poisoning microorganisms to man. Assuit Vet. Med. J., 30 (59): 146-153.

El-Mossalami, M.K. (2002): Bacterial behaviour of some meat products stored in home fridge. Assiut Vet. Med. J. Vol., 47:94.

El-Said, SH. A.A. (2005): Psychrophilic microorganisms in frozen meat products. M.V.Sc. Thesis, Meat Hygiene, Fac. Vet., Med., Zag. Uni. Egypt.

El-Shater, N.S.L. (2010): Evaluation of immunological and bacteriological patterns of some food poisoning micro-organisms (Staphylococcus aureus and Clostridium 
perfringens), Ph. D. Thesis, Microbiol. Dept., Fac. Vet. Med. Zag. Uni. Egypt.

EL-Sherbeeny, M.; Saddik, M.; El-Hossany, M. and Abd-el-Kadir, M. (1990): Staphylococcus aureus associated with meat and meat products Bull. Nut. Instit. A.R.E., 9 (1) 27.

Erlich, H.A.; Gelfand, D. and Sninisky, J.J. (1991): Recent advances in polymerase chain reaction. Science, 252: 1643.

Essa, H.H. and Makar, N.H. (2003): Bacteriological quality of beef burgers in Assiut City, Assiut Vet. Med. J., 49:81-88.

Gehad, F.A.; Eman, M.S. and Takwa, H.I. (2006): Bacteriological and chemical studies of frozen sausage in Giza province. Zag. Vet. J., 34 (1): 156-163.

Guven, K.; Mutlu, B.M.; Gulbandilar, A. and Cakir, $P$. (2010): Occurrence and characterization of Staphylococcus aureus isolated from meat and dairy products consumed in Turkey. J. Food Safety 30: 196-212.

Hoda, A.M.A. and Afaf, A.Y. (2005): Effect of Nisin and Nitrite on some food poisoning microorganisms and their toxins production in frozen sausage. J. Egypt. Vet. Med. Assoc., 65 (3): 113-122.

Huffman, R.D. (2002): Current and future technologies for the decontamination of carcasses and fresh meat. Meat Sci., 62: 285294.

Hwang, S.Y.; Kim, S.H.; Jang, E.J.; Kwon, N.H.; Park, Y.K.; Koo, H.C.; Jung, W.K.; Jun Man Kim, J.M. and Park, Y.H. (2007): Novel multiplex PCR for the detection of the Staphylococcus aureus super antigen and its application to raw meat isolates in Korea. Int. J. Food Microbiol., 117:99-105.

I.C.M.S.F (1978): International Commission on Microbiological Specifications for Foods. Using of several media for identification of Clostridium spices. Univ. of Toronto Press. Toronto, Canada.

Jablonski, L.M. and Bohach, G.A. (2001): Staphylococcus aureus. In: M.P.

Jorgensen, H.; Mork, T.; Caugant, D.A.; Kearns, A. and Rørvik, L.M. (2003): Genetic Variation among Staphylococcus aureus strains from Norwegian Bulk Milk. Appl. Environ. microbiol. p. 835.

Kevin, E.; Juan, C. and Hans, R. (2009): Incidence of Staphylococcus aureus and associated risk factors in Nham, a Thai fermented pork product. Food Microbiol., 26 (5): 547.

Krakauer, T. (1999): Immune response to Staphylococcal super antigens. Immunol Res 20, 163-173.

Letertre, C.; Perelle, S.; Dilasser, F. and Fach, P. (2003a): Detection and genotyping by realtime PCR of the staphylococcal enterotoxin genes sea to sej. Mol Cell Probes. 17(4):139.
Mehrotra, M.; Wang, G. and Johnson, W.M. (2000): Multiplex PCR for detection of genes for Staphylococcus aureus enterotoxins, exfoliative toxins, toxic shock syndrome toxin 1 , and methicillin resistance. J. Clinic. Microbiol.; 38:1032-5.

Monday, S.R. and Bohach, G.A. (1999): Use of multiplex PCR to detect classical and newly described pyrogenic toxin genes in Staphylococcal isolates. J. Clinic. Microbiol.; 37:3411-4.

Najera-Sanchez, G.; Maldonado-Rodriguez, R.; Olvera, P.R and de la GarzaL, M. (2003): Development of two multiplex polymerase chain reaction for the detection of enterotoxigenic strains of Staphylococcus aureus isolated from foods. J Food Prot; 66:1055-62.

Nossier, A.M.M. (2010): Control of microbiological hazard of some meat products preserved at refrigeration, M.V.Sc. Thesis (Meat Hygiene), Fac. Vet. Med. Zag. Univ. Egypt.

Oh, S.K.; Lee, N.; Cho, Y.S.; Shin, D.B.; Choi, S.Y. and Koo, M. (2007): Occurrence of toxigenic Staphylococcus aureus in ready-to-eat food in Korea. J. Food Prot. 70(5):1153.

Omoe, K.; Ishikawa, M.; Shimoda, Y.; Hu, D.L.; Ueda, S. and Shinagawa, K. (2002): Detection of seg, seh, and sei genes in Staphylococcus aureus isolates and determination of the enterotoxin productivities of $\mathrm{S}$. aureus isolates Harboring seg, seh, or sei genes. J. Clin Microbiol. 40 (3):857.

Orwin, P.M.; Fitzgerald, J.R.; Leung, D.Y.; Gutierrez, J.A.; Bohach, G.A. and Schlievert, P.M. (2003): Characterization of Staphylococcus aureus enterotoxin L. Infect Immun 71, 2916-2919.

Oxoid (1998): The oxoid manual 8th edition. Oxoid, Basingstoke, England.

Pinto, B.; Chenoll, E. and Aznar, R. (2005): Identification and typing of food-borne Staphylococcus aureus by PCR-based techniques. Sys. Appl. Microbiol., 28: 340352.

Ramasastry, P.; Rao, M.R. and Mrunalini, N. (1999): Bacterial profiles of frozen meat. Indian Vet. J., 5409-411.

Ranucci, D.; Miraglia, D.; Branciari, R.; D'Ovidio, V. and Severini, M. (2004): Microbiological characteristics of hamburgers and raw pork sausages, and antibiotic-resistance of isolated bacteria. Vet. Res. Communic., 28(1), 269272.

Rao, K.S.; Patish, V.K. and Ghodeker, D.R. (1980): Screening kulfi for staphylococcal enterotoxins with the thermonuclease test. J. Food Prot., 43 (1): 49 . 
Rashad, F.M. (1990): Microbiological studies on Egyption Fresh sausage. Arch. Fur lebensmitt. Hyg. 41 (1):11.

Ruzickova, V.; Karpiskova, R.; Pantucek, R.; Pospisilova, M.; Cernikova, $P$. and Doskar, J. (2008): Genotype analysis of enterotoxin H-positive Staphylococcus aureus strains isolated from food samples in the Czech Republic.Int. J. Food Microbiol., 121 :60-65.

Salek, M. (2000): Microbial control of cooked meat foods and lettuces served in Beheshti Medical Sciences University restaurants. Ph. D. Thesis; (154): 63-9.

Sears, C.L. and Kaper, J.B. (1996): Enteric bacterial toxins: mechanisms of action and linkage to intestinal secretion. Microbiol Rev 60, 167215.

Shahraz, F.; Dadkhah, H.; Khaksar, R.; Mahmoudzadeh, M.; Hosseini, H.; Kamran, M. and Bourke, P. (2012): Analysis of antibiotic resistance patterns and detection of mecA gene in Staphylococcus aureus isolated from packaged hamburger. Meat Sci., 90: 759-763.

Soultos, N.; Abrahim, A. and Abrosiadis, I. (2003): Incidence of some food born bacterial pathogens in traditional sausages produced in northen Greece. Archiv. Furer. Lebensmittel. Hygiene, 54(3):55-57.
Stewart, C.M.; Cole, M.B. and Schaffner, D.W. (2005): Managing the Risk of Staphylococcal Food Poisoning from Cream-Filled Baked Goods to Meet a Food Safety Objective. J. Food Prot. (66) 7: 1310.

Tavakoli, H.R. and Riazipour, M. (2008): Microbial quality of cooked meat foods in Tehran university's restaurants. Pak. J. Med. Sci., 24 (4): 595-599.

Tharwat, A.E. (2008): Microbial aspects of some meat products with a trial to improve their quality and shelf life at refrigeration, M.V.Sc. Thesis (Meat Hygiene), Fac. Vet. Med. Zag. Univ. Egypt.

Velusamy, V.; Arshak, KH.; Korostynska, O.; Oliwa, K. and Adley, C. (2010): An overview of food borne pathogen detection: In the perspective of biosensors Advances, 28(2):232-254.

Vorster, S.M.; Greebe, R.P. and Nortje, G.L. (1994): Incidence of Staphylococcus aureus and Escherichia coli in ground beef, broilers and processed meat in Pretoria, South Africa. J. Food Prot., 57(4):305-310.

Zschock, M.; Kloppert, B.; Wolter, W.; Hamann, H.P. and Lammler, C.H. (2005): Pattern of enterotoxin genes seg, seh,sei and sej positive Staphylococcus aureus isolated from bovine mastitis. Vet. Microbiol., 108(3-4): 243.

\section{الكثف عن وجود ميكروب المكور العنقودى الذهبى المفرز للسموم المعوية فى بعض منتجات اللحوم}

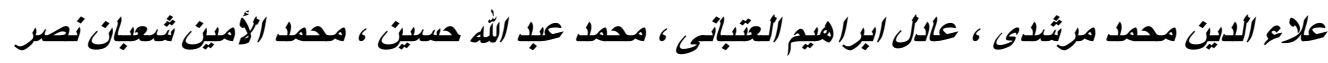

\footnotetext{
تُعد منتجات اللحوم مصدراً هاماً من مصادر البروتين الحيو انى نظر الإحتو ائها على العديد من العناصر الغذائية العائة مثل الفيتامينات

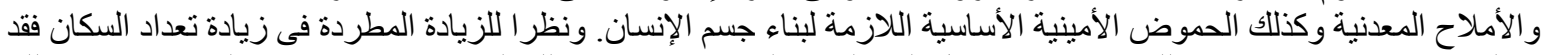

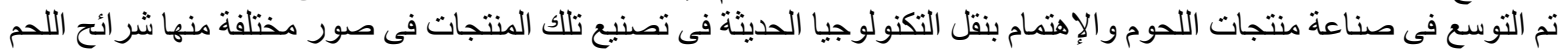

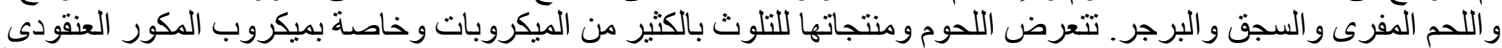

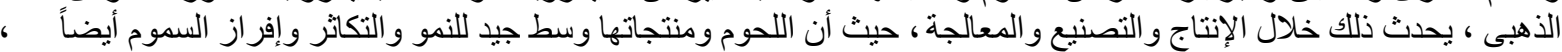

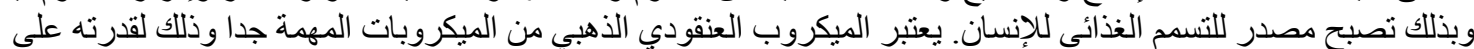

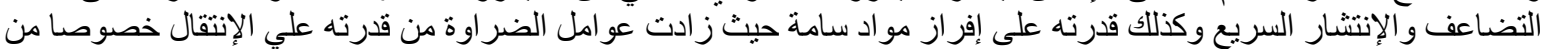

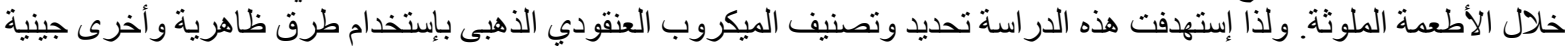

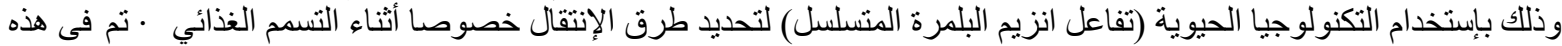

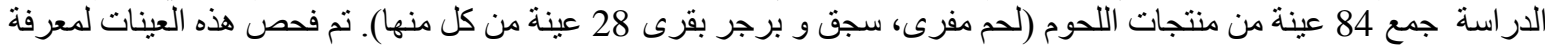

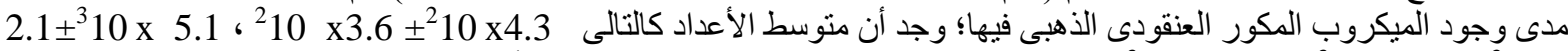

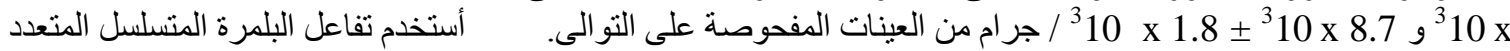

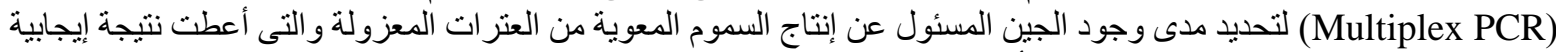

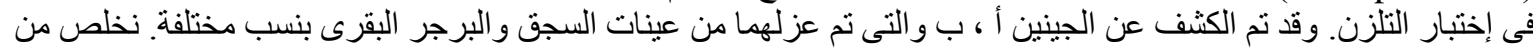

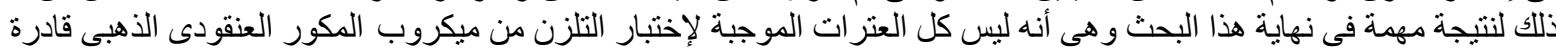
على إفراز السموم المعوية وإحداث التسمه.
} 